\title{
ANMELDELSER
}

ANNETTE KJAER

\section{En mageløs historie}

Ole Jensen: Historien om K.E. Logstrup,

Anis, 2007. 286 sider. 248,- kr.

I slutningen af 2007 udkom en bog af et sjældent format. Bogen er dr. theol. Ole Jensens personlige fortælling om filosoffen, teologen, debattøren, lære- hær ren, kollegaen, vennen og mennesket att K.E. Løgstrup, og er samtidig Ole Jensens forsøg på at "aflægge regnskab for et halvt århundredes beskæftigelse med Løgstrups tænkning".

Med varme og venlighed og intenst let opgave, men i det punkt og med det vedholdende tager Ole Jensen læseren mål for øje begyndte Løgstrup sin lange med på en guidet tur i Løgstrups tænk- vandring for ad tænkningens vej at gøre ning. Fortroligt og med et blændende det "plausibelt at vor og altings væren og overskud viser han rundt $i$ et mage- de livgivende måder, vi og alting holdes løst univers. Ruten er nøje planlagt, og oppe på, er Guds værk”, som Ole Jenbogen er som et landkort over de mange sen sammenfatter det. tankespor i Løgstrups tænkning. Stilfærdigt, men sikkert tegnes billedet af en af århundredes allerstørste tænkere, et hel- '”t hedsbillede hvor teologi, filosofi, etik og for hverdagsglimt væves ind i hinanden.

Bogen giver med sin klare og ud- det, Ole Jensen formår også på forunførlige indholdsfortegnelse mulighed derligste vis og med fortælleformen for at vælge ud og vælge fra efter præ- som vigtigste redskab at løfte den forferencer og niveau. Interesserer man udsætningsløse læser gennem de mere sig udelukkende for Løgstrups filosofi, komplicerede dele af Løgstrups tænkhans teologi eller hans etik, kan afsnit- ning. Fremmedord og fagtermer undtene læses løsrevet fra sammenhængen. gås ikke, men medtages og forklares Men Ole Jensen selv tager det hele med undervejs. I den relevante sammenhæng 
klædes læseren på til at forstå Løgstrups vende; "at kende at verden er Guds". tænkning i en idéhistorisk og teologisk Ole Jensen fremhæver to store opgør; kontekst, når Ole Jensen med sans for et filosofisk opgør med Kant og den det væsentlige kort gennemgår idéhi- kantianske tænkning, der har opgivet at storiske forløb og giver "et lynkursus i finde Gud i den ydre, sansbare verden, kristendom". Personlige beretninger og og et teologisk opgør med Kierkegaard eksempler fra litteraturen og den virke- og den kierkegaardske tænkning, hvor lige verden åbner for forståelsen og gør Gud bliver til i troens "øjeblik". Tro er det undertiden svært tilgængelige stof på trods af fornuften. Videnskaben og levende, vedkommende og poetisk. Be- teologien deler virkeligheden mellem sig tagende godt er det lille uddrag fra Mar- i den kierkegaardske tænkning, forklarer tin A. Hansens Logneren, som Ole Jensen Ole Jensen. Løgstrup derimod aner, at bruger til at forklare forskellen mellem "der må være en erkendemåde ved siden den kausale forståelse, der nås gennem af den videnskabelige, og den må være den videnskabelige undersøgelse og dis- oprindeligere end den videnskabelige". sekering og den analoge forståelse, som Derfor må der et opgør til, et opgør, der poesien kan opfange.

ifølge Ole Jensen forløber over næsten

Med stor omhu indvier Ole Jensen 35 år.

læseren i selv de vanskeligste områder Anden del bærer overskriften "Udaf Løgstrups tænkning. Man fornem- førelse - Filosofi” og her følger Ole mer, at der står noget vigtigt på spil. Jensen Løgstrups vandring frem mod At der her udfoldes noget væsentligt målet. Den etiske fordring og de suveom menneskelivet, dets omgivelse og ræne livsytringer er stadier og vigtige ophav, som man ville gå fattigere gen- støttepunkter på vejen. Begreberne og nem verden uden kendskab til. Derfor deres rækkevidde forklares undervejs, læser man uvilkårligt videre igennem alle på samme måde som Ole Jensen udrebogens tre dele, der progressivt redegør der endnu et løgstrupsk opgør med datifor udviklingen i Løgstrups livslange dens toneangivende tænkere. Kants opærinde.

fattelse, at "sansning og forståelsen er så

Første del er en beskrivelse af Løg- spundet sammen, at de ikke kan skilles strups afsæt; hans baggrund, opvækst ad" rejser Løgstrups modtese: at "forog udvikling, den personlige såvel som ståelse og sansning spiller sammen uden den faglige. Sideløbende hermed tegner at lave om på hinanden”. Og Løgstrup Ole Jensen et knivskarpt billede af de går endnu længere, idet han om sansninopgør med "epokens irreligiøse filosofi gen hævder, at den er en betingelse for " og "epokens irreligiøse religion", som forståelsen og går forud for denne. Som Løgstrup nødvendigvis måtte tage for ved et metafysisk kvantespring bevæger at rydde plads for sit egentlige foreha- Løgstrup sig hermed ud over tidens be- 
tydning for den menneskelige tilværelse teodicéproblemet i almindelighed og og rangordner ontologisk eksistensens hos Løgstrup i særdeleshed må særligt tidslighed under rummet, som sansnin- fremhæves. Ole Jensen formår endnu en gen er knyttet til. "Tiden er truende", gang at gøre det fagspecifikke ikke blot men i rumlige, ydre forekomster for- alment forståeligt, men også alment vedundes det os undertiden "at glemme kommende. Igen åbenbares det, at Løgtiden". "Det er rummelighedens nåde", strup, selv i de filosofiske hovedværker, siger Ole Jensen. Således sprænger Løg- dybest set er en "folkelig" tænker, fordi strup sig vej ud i universet og efterlader hans emner angår forhold af "den dyikke kun Kant og Kierkegaard tilbage beste eksistentielle betydning for ethvert på jorden, men nu også Heidegger, for menneske. Men ofte kræver det faglige hvem det ifølge Ole Jensen aldrig lyk- forudsætninger at læse dem" som Ole kedes at nå ud over det antropo-fæno- Jensen udtrykker det og henviser til læmenologiske, hvor historiciteten og det selisten bagerst i bogen, hvor Løgstrups tidslige er det bærende. Løgstrup har værker og øvrige skrifter er opstillet nu bevæget sig ud i det kosmo-fæno- efter sværhedsgrad.

menologiske, hvilket får Ole Jensen til I afsnittet om Løgstrups etiske forat fastslå at: "Løgstrups sansefilosofi er fatterskab redegør Ole Jensen for, hvorsuveræn nytænkning, forbløffende og ledes Løgstrups etiske synspunkter for mærkelig - inde på dybder, hvor knap en stor dels vedkommende udvikledes nogen tænker har bevæget sig". via hans samfundsengagement, hvor

Ole Jensen fortsætter anden del med han ivrigt debatterede alt fra nazisme og en fornem indføring i andre Løgstrup- atomkrig til seksualmoral og miljø. Men begreber såsom "stemtheden" og "det Ole Jensen udfolder også Løgstrups singulære universale" og slutter afsnit- særegne etik og viser, hvorledes etikkens tet der, hvor den metafysiske undren og grundfænomen for Løgstrup er "førespørgen afløses af religionsfilosofiske tisk". Det etiske grundfænomen er ikke "svar". "Det lægger en religiøs tydning "pligten" som hos Kant og Kierkegaard, nær" er Løgstrups "svar" på de metafy- eller "dyden" som hos Aristoteles, men siske gåder. Ole Jensen runder af med at findes i den givne tilværelse, som den nu konstatere, at der nu blot står tilbage "at engang foreligger på forhånd, hævder skildre Løgstrups teologi i lyset af hans Løgstrup. Ole Jensens gennemgang af filosofi”. Således gives bolden op til den Løgstrups etik viser, hvor aktuel Løgtredje og sidste del af bogen. strups tænkning er også i dag, hvor de

Tredje del udfolder som lovet kon- etiske dilemmaer står i kø.

sekvenserne af Løgstrups tænkning, Historien om K.E. Logstrup er en som disse kommer til udtryk i teologi mageløs historie om en usædvanlig og og etik. Ole Jensens redegørelse for forbløffende tænker, der sprængte tænk- 
ningens rammer og viede sit liv til at vise menneskene, at "en almægtig Række af haandgribelige Mirakler er Verden, en Fontæne af Glæde, Ophav til din Tanke." - Her sagt med et lån fra Johs. V. Jensen.

Bogen er også en mageløst fortalt historie. Det er meget vanskeligt at finde mangler eller overflødige afsnit. Skulle der indvendes noget, må det blive et lille hjertesuk over, at Ole Jensen af hensyn til bogens omfang og form har valgt kun sporadisk at strejfe Løgstrups kunst- og sprogfilosofi. To områder, der kunne have været umådeligt spændende at få belyst af netop Ole Jensen, der i bogen demonstrerer sans for såvel kunst som sprog.

Historien om K. E. Logstrup kan med fordel og stort udbytte bruges som introduktion til Løgstrups forfatterskab, s som grundbog i studiekredse eller til al- i mindelig lystlæsning. Men selvom bogen kerc er tænkt og skrevet med også "den nye ken læser" i tankerne, er den på ingen måde en light-udgave af Løgstrups tænkning. Tværtimod. Den er et destilleret udtræk et af det væsentligste i Løgstrups tænk- Bec ning, fortalt og formidlet som en mage- $i$ løs historie.
PAW HEDEGAARD AMDISEN

\section{Their way?}

Quentin Skinner: Politik og historie, Hans

Reitzels Forlag, 2009, introduktion af

Frank Beck Lassen \& Mikeel Thorup, 275

sider, 299,-kr.

Det er glædeligt, at vi nu får adgang til nogle af den engelske idéhistoriker Quentin Skinners væsentligste artikler i en dansk version. Skinners tilgang til det idéhistoriske felt - både praktisk og metodologisk - er i de senere år kommet til at fylde mere og mere i idéhistoriske kredse rundt omkring i verden - herunder i Danmark. Og selvom vi hele tiden har haft adgang til Skinners tekster på et i særdeleshed formfuldendt engelsk, så er jeg sikker på, at den danske oversættelse vil give endnu flere idéhistorisk interesserede og kommende idéhistorikere herhjemme lejlighed til at stifte bekendtskab med Skinners uomgængelige overvejelser.

Men hvad er det, der gør Skinner til et uomgængeligt bekendtskab? Frank Beck Lassen og Mikkel Thorup peger deres fremragende og grundige introduktion til artikelsamlingen på en række faktorer, som det kunne værd at pege på i denne sammenhæng, og som også viser, at det forskningsprogram, Skinner har søsat for den idéhistoriske forskning, p.t. er et af de mest lovende. Kun tangeret af de forskningsprogrammer, der er blevet søsat i forlængelse af Michel Foucault og den begrebshistoriske 